\title{
Попов А.В. \\ Алгоритм действия руководителя УМВД в организации оперативно-розыскной деятельности по раскрытию убийств, в том числе по найму
}

Академия управления МВД России

(Россия, Москва)

doi:10.18411/spc-22-01-2018-16

idsp: 000001:spc-22-01-2018-16

В работе по раскрытию убийств совершенных по найму большое значение имеет деятельность отдела (отделения, группы) по раскрытию преступлений против личности УМВД, на первоначальном этапе раскрытия неочевидных преступлений в течение первых суток, после совершения убийства имеющего признаки «заказного», или по истечении десяти суток при условии непрерывности работы по раскрытию.

В оперативно-розыскной деятельности, прописной истиной является то, что там, где оперативно-розыскные мероприятия проводятся целеустремленно и продуманно, убийства в своем большинстве раскрываются в течение первых (дежурных) суток.

Под раскрытием преступлений по «горячим следам» понимается комплекс оперативно-розыскных мероприятий, следственных действий, осуществляемых немедленно после обнаружения факта убийства, обеспечивающих установление лиц, его совершивших в течение кратчайшего срока, но не свыше трех суток. Успешная работа по раскрытию убийств по «горячим следам», во многом обусловлена постоянной оперативной готовностью органов внутренних дел на районном уровне. Здесь имеется в виду состояние готовности органа внутренних дел, его подразделений, которое обеспечивает наиболее быстрый, полный и целесообразный ввод в действие всех сил и средств. Такая готовность включает в себя быстрое оповещение органов внутренних дел на районном уровне о совершенном преступлении. Сообщения, как правило, поступают на пульт оперативному дежурному, который, прежде всего, организует проверку полученной информации и после её подтверждения организует работу по охране места происшествия, направляя на место преступления, находящихся в его оперативном подчинении наряды ППСП, либо группу немедленного реагирования, которые по прибытии выясняют обстановку, докладывают дежурному и ждут прибытия следственно- оперативной группы. Зачастую, наряды, которые первыми прибыли на место происшествия, получают информацию о путях отхода вероятного преступника, и, после организации охраны места преступления, с указания оперативного дежурного осуществляют преследование и задержание преступника «по горячим следам». В случаях когда проверка сообщения о преступлении затягивается, а наряды пребывают с опозданием, при этом не грамотно осуществляется охрана места происшествия, раскрытие преступления может затянуться, в лучшем случае на месяцы и годы, а в противном случае остаться не раскрытым.

В дальнейшем оперативный дежурный, докладывает начальнику и руководству ( заместителю начальника- начальнику полиции, заместителю начальника полиции по оперативной работе, начальнику УУР и др.) УМВД о регистрации подобного факта, по указанию выше указанных руководителей направляет на место происшествия оперативно-следственную группы в составе: представителя руководства УМВД, следователя, оперуполномоченных УУР, эксперта-криминалиста, кинолога со служебно- розыскной собакой, судебно-медицинского эксперта, участкового уполномоченного, обслуживающего эту территорию. В случае необходимости, оперативный дежурный может, по согласованию с руководством, задействовать соответствующий оперативный план по розыску и задержанию скрывшегося преступника, который позволяет расширить географию розыска и увеличить возможность раскрытия преступления в кратчайшие сроки (например, оперативный план «Перехват» и др.). 
После организации выезда СОГ, оперативный дежурный УМВД области постоянно поддерживает с ней связь, принимая сообщения членов СОГ с места происшествия и обеспечивая ее обработку и систематизацию.

Основная часть раскрытия убийства по «горячим следам» ложится на следственно-оперативные группы, состоящие из следователя СУСК, сотрудников уголовного розыска, a также сотрудников других подразделений полиции. Следственно-оперативные группы могут быть как постоянно действующими, так и созданными непосредственно для раскрытия конкретного убийства или другого тяжкого преступления против личности.

В связи с процессуальной независимостью следователя, на него возлагается ответственность за проведение осмотра места происшествия, осмотра трупа. Все участвующие в осмотре лица должны оказывать следователю помощь в разрешении возникающих при этом вопросов. Как известно, качественно проведенный осмотр, независимо от вида преступления, является залогом успеха, если обнаруженная при осмотре места происшествия доказательственная база была качественно закреплена.

При осмотре места происшествия оперативный сотрудник уголовного розыска, используя метод оперативного осмотра, уясняет картину происшедшего в целом, что позволяет выяснить способы убийства, время совершения преступления, личность потерпевшего и другие важные моменты (возможный мотив, орудие совершения преступления, обстоятельства и др.). Совместно с кинологом решается вопрос о применении служебно-розыскной собаки. С целью установления личности убитого оперуполномоченный УР тщательно осматривает труп потерпевшего, его документы, содержимое его карманов, наличие на его теле татуировок и других признаков, которые могут оказать помощь в идентификации трупа. Естественно, что все эти действия фиксируются следователем, и все изъятое из одежды трупа вносится в протокол осмотра места происшествия и приобщается к делу. Производится поквартирный (подворный) обход. С течением времени суток организуется проверка мест возможного отхода или укрытия преступника (подвалы, чердаки, теплотрассы, притоны). В случае если убийство не раскрывается «по горячим следам», не следует пренебрегать повторным осмотром места преступления, подворным обходом, либо возвращением к отработке иных лиц или версий, зачастую это приводит к неожиданным результатам и способствует раскрытию рассматриваемых преступлений.

C первых же шагов на месте происшествия оперативный сотрудник обязан выявлять лиц, с помощью которых можно составить словесный портрет преступника.

К работе по раскрытию преступлений «по горячим следам», по убийству необходим скрупулезный учет поступающей информации, учет лиц, получающих задание по отработке различных версий и результатов их работы с тем расчетом, чтобы не пропустить полезные сведения и не дублировать исполнение. Для этого необходимо уже с самого начала расследования выделить оперативного сотрудника ОУР, который бы вел учет всей поступающей информации, ее отработку, результаты.

С учетом полученных данных об обстоятельствах и способе совершения преступления, определяется круг подозреваемых и организуется их проверка, в том числе по учетам.

Важное место в работе оперуполномоченного занимает осмотр трупа, совместно с соответствующими специалистами. Это позволяет в некоторых случаях определить характер повреждений, либо следы, имеющиеся на преступнике.

$$
* * *
$$

1. Парфенов А.В. Некоторые особенности в построении и выработке версий по раскрытию убийств, связанных с безвестным исчезновением граждан // Научный портал МВД России. 2012. №2. С. 51 52.

2. Парфенов А.В. К вопросу о взаимодействии оперативных и следственных подразделений при раскрытии убийств, связанных с безвестным исчезновением граждан / А.В. Парфенов // Труды Академии управления МВД России. 2012. №3. С. 23-24. 